\title{
Metformin induces apoptosis via a mitochondria-mediated pathway in human breast cancer cells in vitro
}

\author{
ZHEN-YUAN GAO ${ }^{1}$, ZHE LIU ${ }^{2}$, MING-HONG BI ${ }^{3}$, JING-JING ZHANG ${ }^{3}$, ZHENG-QUAN HAN $^{3}$, \\ XIAO HAN ${ }^{3}$, HONG-YA WANG ${ }^{3}$, GUO-PING SUN ${ }^{1}$ and HAO LIU ${ }^{2}$ \\ ${ }^{1}$ Department of Oncology, The First Affiliated Hospital of Anhui Medical University, \\ Hefei, Anhui 230032; ${ }^{2}$ Faculty of Pharmacy, Bengbu Medical College, \\ Anhui Engineering Technology Research Center of Biochemical Pharmaceuticals, Bengbu, Anhui 233030; \\ ${ }^{3}$ Department of Oncology, The First Affiliated Hospital of Bengbu Medical College, Bengbu, Anhui 233022, P.R. China
}

Received March 16, 2015; Accepted December 18, 2015

DOI: 10.3892/etm.2016.3143

\begin{abstract}
Breast cancer is the most commonly occurring cancer and second leading cause of mortality in women. Metformin is a widely prescribed anti-hyperglycemic drug, which is emerging as a potential cancer preventative and treatment agent. However, the mechanisms underlying the suppressive effects of metformin on cancer cell growth and the induction of cancer cell apoptosis are not fully elucidated. The present study aimed to identify the pathways regulated by metformin in two breast cancer cell lines, MDA-MB-231 and MDA-MB-435. Cells were treated with various concentrations of metformin and then evaluated with respect to viability, proliferation, adenosine triphosphate (ATP) and reactive oxygen species (ROS) levels, mitochondrial membrane potential $(\Delta \psi \mathrm{m})$, and the expression of anti- and pro-apoptotic proteins. Metformin caused apoptosis in a concentration- and time-dependent manner, and decreased cell viability and ATP production. Furthermore, metformin induced the generation of ROS and decreased the $\Delta \psi \mathrm{m}$. Moreover, metformin downregulated the expression of the anti-apoptotic proteins B-cell lymphoma 2 (BCL-2) and myeloid cell leukemia-1, and upregulated the expression of the pro-apoptotic BCL-2-associated $\mathrm{X}$ protein in MDA-MB-231 cells. These results demonstrate that the apoptotic and cytotoxic effects of metformin on breast cancer cells are mediated by the intrinsic mitochondria-mediated apoptosis pathway.
\end{abstract}

Correspondence to: Professor Guo-Ping Sun, Department of Oncology, The First Affiliated Hospital of Anhui Medical University, 218 Jixi Road, Hefei, Anhui 230032, P.R. China E-mail: sungp@ahmu.edu.cn

Key words: metformin, mitochondria, mediated pathway, apoptosis, breast cancer

\section{Introduction}

Breast cancer is the most common cancer among women worldwide and ranks first and second in cancer mortality rates among women in undeveloped and developed regions, respectively. According to GLOBOCAN 2012 estimates, 1.67 million women were diagnosed with breast cancer in 2012, representing an increase in breast cancer incidence of $>20 \%$ since 2008 (1). Although it is considered a cancer with a relatively good prognosis if diagnosed and treated in a timely manner, the mortality rates from breast cancer remain high, particularly in developing countries, likely because it is often diagnosed at advanced stages $(2,3)$. The majority of breast cancer-related mortalities are due to the development of distant metastasis, for which no effective treatments exist $(4,5)$. Although numerous chemotherapeutic agents are available for the treatment of cancer metastases, no improvement in the median duration of survival has been observed, and the molecular events underlying the progression to metastasis are not completely understood (6).

Apoptosis, also known as programmed cell death, is a process in living organisms that is necessary for the maintenance of proper development and the elimination of cell damage or excess. Apoptosis is characterized by distinct biochemical and morphological changes, including DNA fragmentation, plasma membrane blebbing and loss of cell volume. There are two major pathways by which apoptotic cell death can be induced: The intrinsic (or mitochondrial) pathway and the extrinsic (or death receptor) pathway. The intrinsic pathway regulates the activity of proteins of the survivin and B-cell lymphoma 2 (BCL-2) families. The latter family includes myeloid cell leukemia-1 (MCL-1), which plays an integral role in cell survival and apoptosis (7), and BCL-2-associated X protein (BAX), a pro-apoptotic protein that induces the release of cytochrome $c$ from mitochondria to the cytosol, where it binds to apoptotic peptidase activating factor 1 and facilitates the formation of the apoptosome, leading to the activation of caspase-9 and eventual cell death. The extrinsic pathway is activated by specific ligands that engage death receptors. This process involves Fas, which binds to and activates the caspase- 8 protein $(8,9)$. Thus, caspases are central regulators 
of the apoptotic process, and are involved in the two major apoptosis pathways (10).

Metformin, an oral biguanide drug, has been used widely to treat type 2 diabetes and pre-diabetic conditions for $>40$ years due to its good tolerability profile and low cost. In addition to its anti-diabetic effect, epidemiological studies and basic research have suggested that metformin may reduce the risk of cancer in diabetic patients (11-15). Moreover, a number of clinical studies have shown that the survival rate of cancer patients is improved by treatment with metformin (16-19). These results suggest that metformin might potentially be used as an anticancer drug for different types of cancer. However, the effects and possible mechanisms of action of metformin in the proliferation and apoptosis of breast cancer cells have not been explored in depth. The present study was designed to address this deficiency by investigating the cytotoxic mechanism of metformin in MDA-MB-231 and MDA-MB-435 human breast cancer cells.

\section{Materials and methods}

Reagents and antibodies. Metformin and propidium iodide (PI) were purchased from Sigma-Aldrich. (St. Louis, MO, USA). The fluorescent dyes JC-1 and dihydroethidium (DHE) were purchased from Nanjing KeyGen Biotech Co., Ltd. (Nanjing, China). Rabbit anti-MCL-1 (ab32087; 1:500) and anti-BCL-2 (ab32124; 1:1,000) monoclonal antibodies were obtained from Abcam (Cambridge, UK). Rabbit anti-BAX (5023; 1:1,000) monoclonal antibody was purchased from Cell Signaling Technology, Inc. (Beverly, MA, USA), and rabbit anti- $\beta$-actin polyclonal antibody (sc-130657; 1:1,000) was obtained from Santa Cruz Biotechnology, Inc. (Dallas, TX, USA). Horseradish peroxidase (HRP)-conjugated goat anti-mouse IgG (BL001A; 1:5,000) and goat anti-rabbit IgG (BL003A; 1:5,000) were purchased from Biosharp (Suzhou, China).

Cell lines and cell culture. MDA-MB-231 and MDA-MB-435 breast cancer cells were purchased from Shanghai Cell Bank (Shanghai, China). The cells were inoculated in fresh Dulbecco's modified Eagle's medium containing 10\% fetal calf serum (both Gibco; Thermo Fisher Scientific, Inc., Waltham, MA, USA), $100 \mathrm{U} / \mathrm{ml}$ penicillin and $100 \mathrm{mg} / 1$ streptomycin (both Sigma-Aldrich). Cultures were maintained at $37^{\circ} \mathrm{C}$ in a $5 \% \mathrm{CO}_{2}$ humidified atmosphere.

Cell viability assay. Breast cancer cells were cultured in a 96-well plate for $24 \mathrm{~h}$ at an initial density of $1 \times 10^{5}$ cells/well, prior to treatment with various concentrations $(1.25,2.5,5,10$ and $20 \mathrm{mM}$ ) of metformin for 24,48 or $72 \mathrm{~h}$ at $37^{\circ} \mathrm{C}$. Subsequently, $20 \mu 1$ 3-(4,5-dimethylthiazol-2-yl)-2,5-diphenyltetrazolium bromide (MTT) solution (5.0 mg/l; Sigma-Aldrich) was added to each well and the cells were incubated for a further $4 \mathrm{~h}$. The medium was then removed by gentle aspiration and $150 \mu \mathrm{l}$ dimethyl sulfoxide (Sigma-Aldrich) was added to each well to dissolve the resulting crystals. Absorbance was read at $490 \mathrm{~nm}$ using a microplate reader (Synergy HT; BioTek Instruments, Inc., Winooski, VT, USA). Cell viability was assessed by comparison with control cells treated with vehicle alone.

Colony formation. Colony-forming rates of the tumor cells were determined using a colony formation assay. The breast cancer cells were seeded at 500 cells/well in 6-well plates and incubated for $24 \mathrm{~h}$ at $37^{\circ} \mathrm{C}$. The medium was removed and the cells were then treated with various concentrations of metformin $(0,0.1,0.5$ and $2.0 \mathrm{mM})$ using standard cell culture conditions under a $5 \% \mathrm{CO}_{2}$ humidified atmosphere at $37^{\circ} \mathrm{C}$. After 8 days, the dishes were washed twice with phosphate-buffered saline (PBS), fixed with paraformaldehyde (Sigma-Aldrich) at $-20^{\circ} \mathrm{C}$ for $10 \mathrm{~min}$, and then stained with crystal violet (Thermo Fisher Scientific, Inc.).

Cellular adenosine triphosphate (ATP) levels. Cellular ATP levels were determined by a luciferase-based assay with an ATP Bioluminescence Assay kit (Merck Millipore, Darmstadt, Germany), according to the manufacturer's protocol. Briefly, breast cancer cells $\left(2 \times 10^{6}\right)$ were seeded in each well of a 24-well plate and allowed to reach the exponential growth phase prior to being treated with various concentrations of metformin $(10,20$ and $40 \mathrm{mM})$ for $24 \mathrm{~h}$ at $37^{\circ} \mathrm{C}$. After $5 \mathrm{~h}$, the cells were harvested and centrifuged at $10,000 \mathrm{x}$ g for $5 \mathrm{~min}$ at $4^{\circ} \mathrm{C}$. Supernatants $(100 \mu \mathrm{l})$ were mixed with $100 \mu \mathrm{l}$ ATP detection working solution in a white 96-well plate. Measurements were obtained using a luminometer $\left(\right.$ GloMax $^{\circledR} 96$ Microplate Luminometer; Promega Corporation, Sunnyvale, CA, USA) at an emission maximum of $\sim 560 \mathrm{~nm}$ for $300 \mathrm{sec}$.

Mitochondrial membrane potential $(\Delta \psi m)$. The $\Delta \psi \mathrm{m}$ was assessed using the JC-1 Apoptosis Detection kit (Beyotime Institute of Biotechnology, Jiangsu, China). Briefly, cells were plated in a 12-well plate at a density of $2 \times 10^{6}$ cells/well and treated with metformin $(5 \mathrm{mM})$ for $24 \mathrm{~h}$ at $37^{\circ} \mathrm{C}$. Cells were washed once with PBS and incubated at $37^{\circ} \mathrm{C}$ for $30 \mathrm{~min}$ in medium containing $0.5 \mathrm{ml} \mathrm{JC}-1$. Then, the supernatant was removed and cells were rinsed twice with JC-1 staining buffer. Fluorescence images were observed within 30 min using a fluorescent microscope (Eclipse Ti-U; Nikon Corporation, Tokyo, Japan). A decline in the ratio of red to green fluorescence indicated a loss of $\Delta \psi \mathrm{m}$.

Reactive oxygen species (ROS) levels. The determination of ROS levels was based on the oxidation of DHE. Breast cancer cells were seeded at a density of $2 \times 10^{5}$ cells/well in a six-well plate for $24 \mathrm{~h}$ and incubated with $20 \mathrm{mM}$ metformin for 1,3 and $6 \mathrm{~h}$. The cells were then treated with DHE $(5 \mathrm{mM}$, Beyotime Institute of Biotechnology) for $20 \mathrm{~min}$ at $37^{\circ} \mathrm{C}$ in the dark. The cells were then washed twice and harvested in PBS. The fluorescence of DHE was detected with a flow cytometer (BD Biosciences, Franklin Lakes, NJ, USA) with excitation at $488 \mathrm{~nm}$ and emission at $530 \mathrm{~nm}$.

PI staining and caspase inhibition assays. Apoptosis of the breast cancer cells was determined using a PI apoptosis detection kit (Nanjing KeyGen Biotech Co., Ltd.) according to the manufacturer's protocol. Briefly, breast cancer cells $\left(2 \times 10^{6}\right)$ were plated in each well of a 24 -well plate and allowed to reach the exponential growth phase before being treated with various concentrations of metformin $(5,10$ and $20 \mathrm{mM})$ for $24 \mathrm{~h}$. The cells were then harvested and collected by centrifugation at $1,500 \mathrm{x}$ g for $10 \mathrm{~min}$ at $4^{\circ} \mathrm{C}$, and resuspended in $200 \mu \mathrm{l}$ ice-cold binding buffer. The cell suspensions were incubated with $5 \mu \mathrm{l}$ PI for $10 \mathrm{~min}$ at room temperature in the 
A

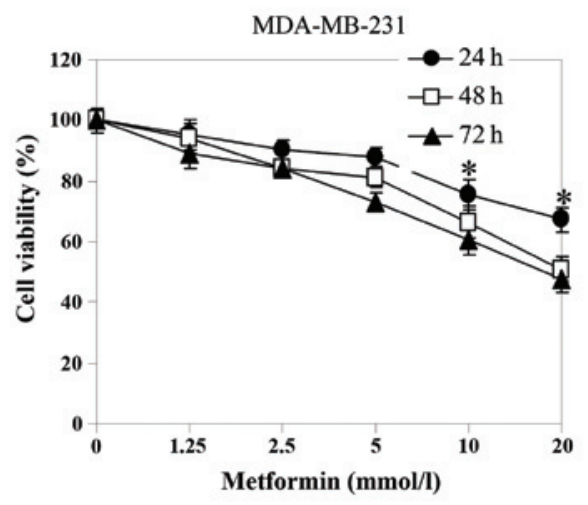

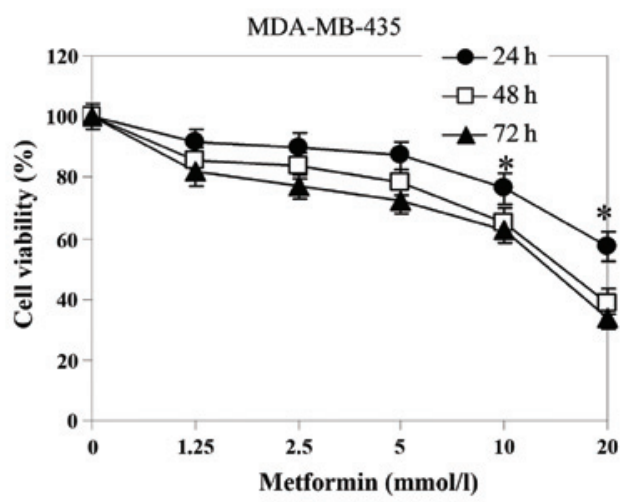

B

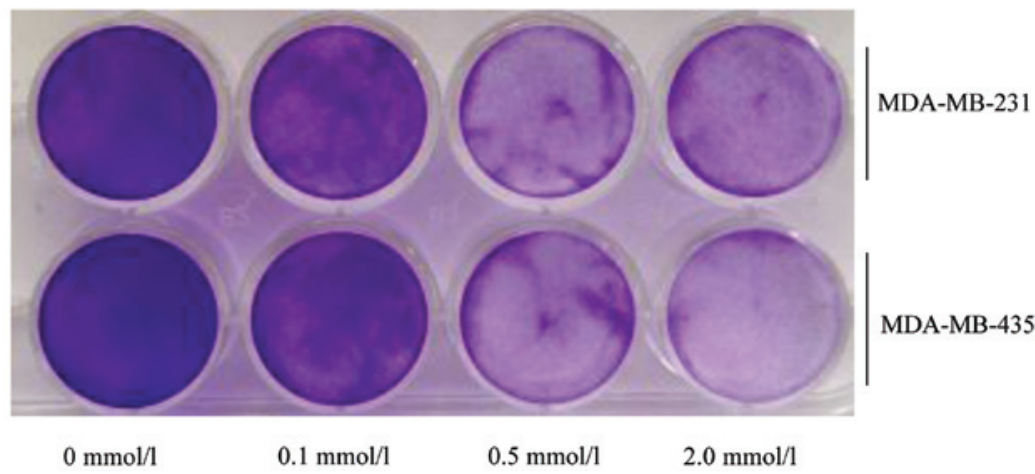

Figure 1. Metformin-induced cytotoxicity of breast cancer cells. (A) MDA-MB-231 and MDA-MB-435 cells were treated with metformin (1.25, 2.5, 5, 10 or $20 \mathrm{mmol} / \mathrm{l}$ ) for 24,48 or $72 \mathrm{~h}$. Cell viability was analyzed using the MTT assay. The results revealed that metformin inhibited the growth of breast cancer cells in a dose- and time-dependent manner. Data are expressed as the mean \pm standard error of the mean. ${ }^{*} \mathrm{P}<0.05 \mathrm{vs}$. the control (0 mmol/1 metformin). (B) MDA-MB-231 and MDA-MB-435 cells were cultured with various concentrations of metformin $(0,0.1,0.5$ and $2 \mathrm{mmol} / \mathrm{l})$ for $24 \mathrm{~h}$ and cell colony formation was analyzed. Colony formation by MDA-MB-231 and MDA-MB-435 cells was inhibited by metformin in a dose-dependent manner. MTT, 3-(4,5-dimethylthiazol-2-yl)-2,5-diphenyltetrazolium bromide.

dark, and the percentage of apoptotic cells was measured by flow cytometry (Accuri ${ }^{\mathrm{TM}}$ C6; BD Biosciences). For caspase inhibitor assays, the cells were pretreated with a pan-caspase inhibitor (z-VAD-FMK; Sigma-Aldrich, Shanghai, China; $20 \mu \mathrm{M})$ for $2 \mathrm{~h}$ and then treated with various concentrations of metformin $(2.5,5,10$ and $20 \mathrm{mM})$ for an additional $24 \mathrm{~h}$. The extent of apoptosis was then determined using the MTT assay.

Western blot analysis. MDA-MB-231 cells treated with metformin $(5 \mathrm{mM})$ were collected at various time points $(0,6$, 16 and $24 \mathrm{~h}$ ), washed twice with ice-cold PBS, and incubated in radioimmunoprecipitation assay protein lysis buffer (Beyotime Institute of Biotechnology) for $30 \mathrm{~min}$ at $4^{\circ} \mathrm{C}$. The lysates were centrifuged at $13,000 \mathrm{xg}$ for $10 \mathrm{~min}$ at $4^{\circ} \mathrm{C}$. The concentrations of total lysate protein were detected by a standard Bradford assay (Bio-Rad Laboratories, Inc., San Diego, CA, USA), resolved by $10 \%$ sodium dodecyl sulfate-polyacrylamide gel electrophoresis (Beyotime Institute of Biotechnology), and transferred to nitrocellulose membranes (Bio-Rad Laboratories, Inc.). The nitrocellulose membranes were blocked with $5 \%$ non-fat milk at room temperature for $1 \mathrm{~h}$ and then incubated overnight at $4^{\circ} \mathrm{C}$ with rabbit anti-BCL-2 (1:1,000), anti-MCL-1 (1:500), anti-BAX $(1: 1,000)$ and anti- $\beta$-actin $(1: 1,000)$ primary antibodies. After washing the membranes three times for $10 \mathrm{~min}$ each with Tris-buffered saline containing Tween-20, they were incubated with HRP-conjugated secondary antibodies (1:5,000 dilution). Proteins were visualized using an Enhanced
Chemiluminescence-Plus kit (Nanjing KeyGen Biotech Co., Ltd.).

Statistical analysis. All experiments were performed at least in triplicate. Data are expressed as the means \pm standard error of the mean (SEM). Statistical analyses were performed using one-way analysis of variance with SPSS software version 20.0 (IBM SPSS; Armonk, NY, USA). Differences were considered statistically significant at $\mathrm{P}<0.05$.

\section{Results}

Metformin inhibits the viability and colony formation of breast cancer cells. MDA-MB-231 and MDA-MB-435 cells were treated with metformin at different concentrations (1.25, $2.5,5,10$ or $20 \mathrm{mmol} / \mathrm{l}$ ) for 24,48 or $72 \mathrm{~h}$. MTT and colony formation assays were then conducted to assess cell proliferation. As shown in Fig. 1A, metformin significantly decreased cell viability in a concentration- and time-dependent manner. In addition, metformin inhibited cell colony formation in a concentration-dependent manner (Fig. 1B).

Metformin decreases $\Delta \psi m$ and the production of ATP. The $\Delta \psi \mathrm{m}$ and its loss are near-universal hallmarks of, and critical steps for, subsequent cell death (20). In addition, $\Delta \psi \mathrm{m}$ and the generation of ATP reflect mitochondrial function. Therefore, the effect of a $24-\mathrm{h}$ treatment with metformin $(5 \mathrm{mM})$ on $\Delta \psi \mathrm{m}$ 
A

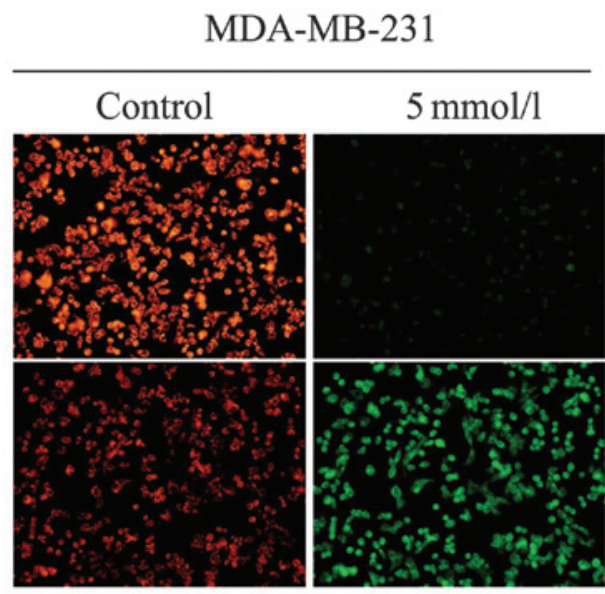

B

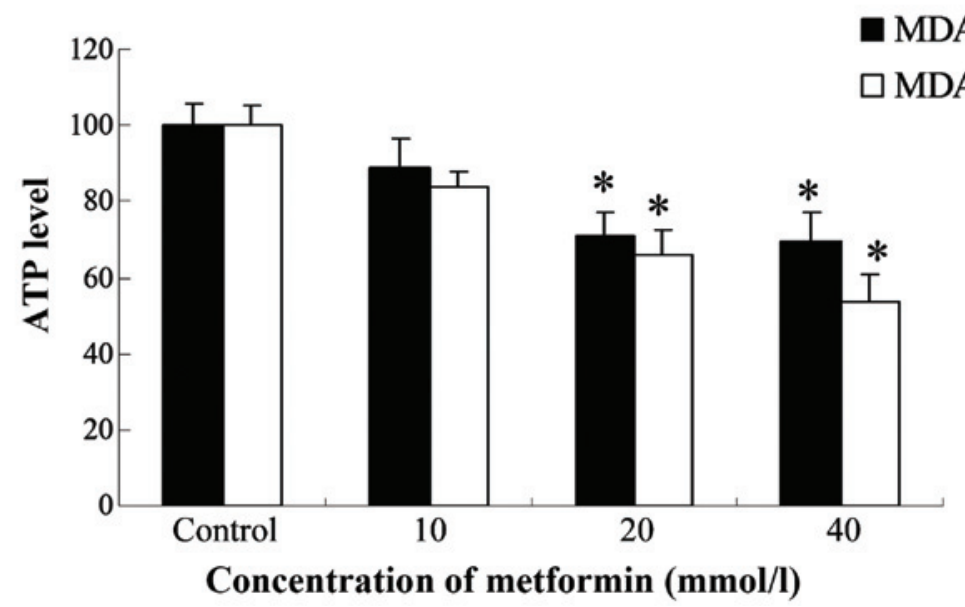

MDA-MB-435

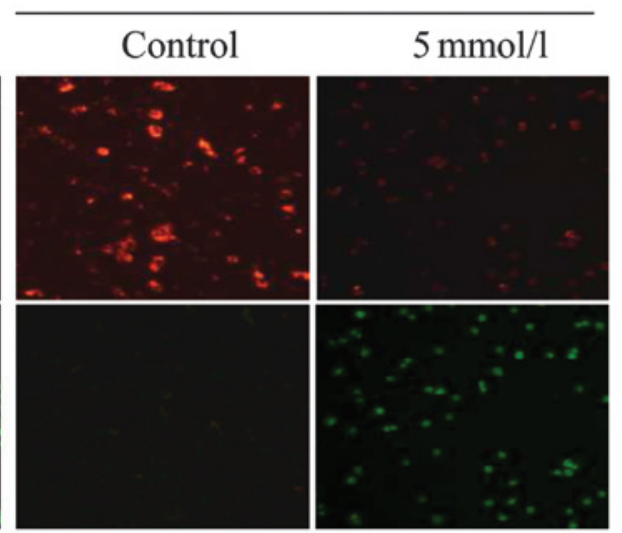

MDA-MB-231

MDA-MB-435

Figure 2. Metformin downregulated the mitochondrial membrane potential $(\Delta \psi \mathrm{m})$ and ATP production. (A) MDA-MB-231 and MDA-MB-435 cells were treated with $5 \mathrm{mmol} / 1$ metformin for $24 \mathrm{~h}$. Changes in $\Delta \psi \mathrm{m}$ were monitored by loading with the fluorescent probe JC-1 and analyzed by fluorescence microscopy. Images of the cells were then captured under a light microscope (magnification, x200). Metformin increased the green to red fluorescence intensity ratio, suggesting that $\Delta \psi \mathrm{m}$ was reduced in metformin-treated breast cancer cells. (B) MDA-MB-231 and MDA-MB-435 cells were incubated with various concentrations of metformin (10, 20 or $40 \mathrm{mmol} / \mathrm{l})$ for $24 \mathrm{~h}$. Absorbance was measured using a luminometer. Metformin reduced ATP levels in MDA-MB-435 cells in a concentration-dependent manner. In MDA-MB-231 cells, ATP levels were maximally reduced at 20 mmol/1 metformin and were not further decreased by $40 \mathrm{mmol} / \mathrm{l}$. Data are expressed as the mean \pm standard error of the mean. ${ }^{*} \mathrm{P}<0.05$ vs. the control.

was investigated in MDA-MB-231 and MDA-MB-435 cells. The $\Delta \psi \mathrm{m}$ was reduced in metformin-treated cells as shown by the significant reduction in red fluorescence and increase in green fluorescence generated by JC-1 (Fig. 2A). The shift from red to green fluorescence was more notable in MDA-MB-231 cells than in MDA-MB-435 cells.

To study the effect of metformin on cellular ATP production, the two breast cancer cell lines were treated with different concentrations of metformin $(10,20$ and $40 \mathrm{mM})$ for $24 \mathrm{~h}$. The ATP levels of metformin-treated MDA-MB-231 and MDA-MB-435 cells were reduced compared with those in the respective control group. The lowest level was observed at a metformin concentration of $40 \mathrm{mM}$ in MDA-MB-435 cells (Fig. 2B). In MDA-MB-231 cells, the lowest ATP level was observed following treatment with $20 \mathrm{mM}$ metformin, and was not further reduced when the concentration of metformin was increased to $40 \mathrm{mM}$.

Metformin increases ROS production. As ROS generation is a common after-effect of a reduction in $\Delta \psi \mathrm{m}(21,22)$, changes in the levels of ROS were measured by DHE fluorescence.
MDA-MB-231 and MDA-MB-435 cells treated with metformin (20 $\mathrm{mM})$ for various durations $(1,3$ and $6 \mathrm{~h}$ ) showed an increase in green fluorescence in a time-dependent manner (Fig. 3A). Flow cytometric analyses demonstrated that $20 \mathrm{mM}$ metformin caused an increase in ROS production, as compared with the control cells. The results of flow cytometry were consistent with the fluorescence images, suggesting that metformin caused an accumulation of ROS in breast cancer cells.

Metformin-induced apoptosis is a caspase-dependent process. The type of cell death induced in breast cancer cells treated with metformin was determined by PI staining. Following incubation with metformin for $24 \mathrm{~h}$, the extent of apoptosis in MDA-MB-231 cells markedly increased from $7.0 \%$ with $5 \mathrm{mM}$ metformin to $39.6 \%$ with $20 \mathrm{mM}$ metformin. MDA-MB-435 cells were less sensitive to metformin, as the percentage of cells undergoing apoptosis only increased from 2.9 to $17.7 \%$ (Fig. 3B).

To confirm whether the metformin-induced cell death observed in MDA-MB-231 cells was a result of apoptosis, the pan-caspase inhibitor z-VAD-FMK was used to examine 
A

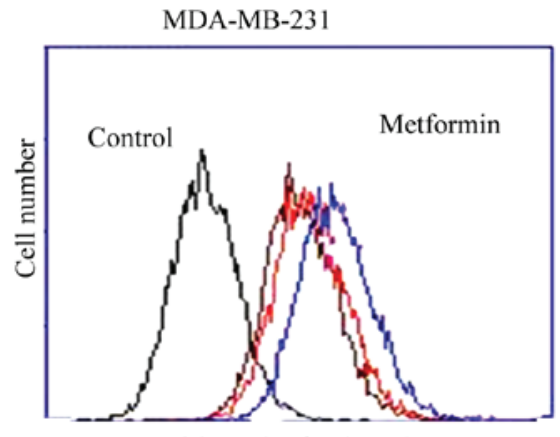

ROS production(DHE)

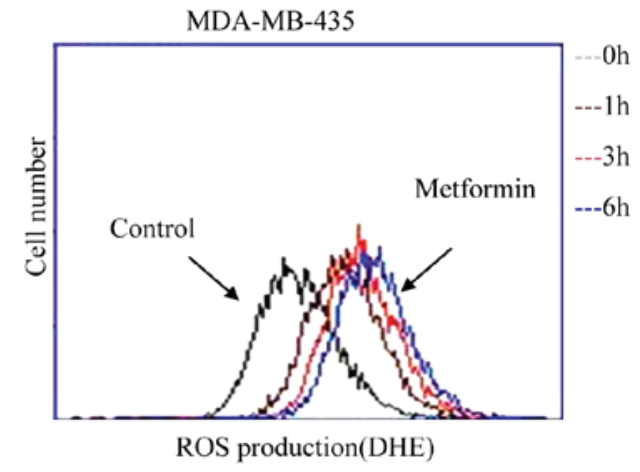

B

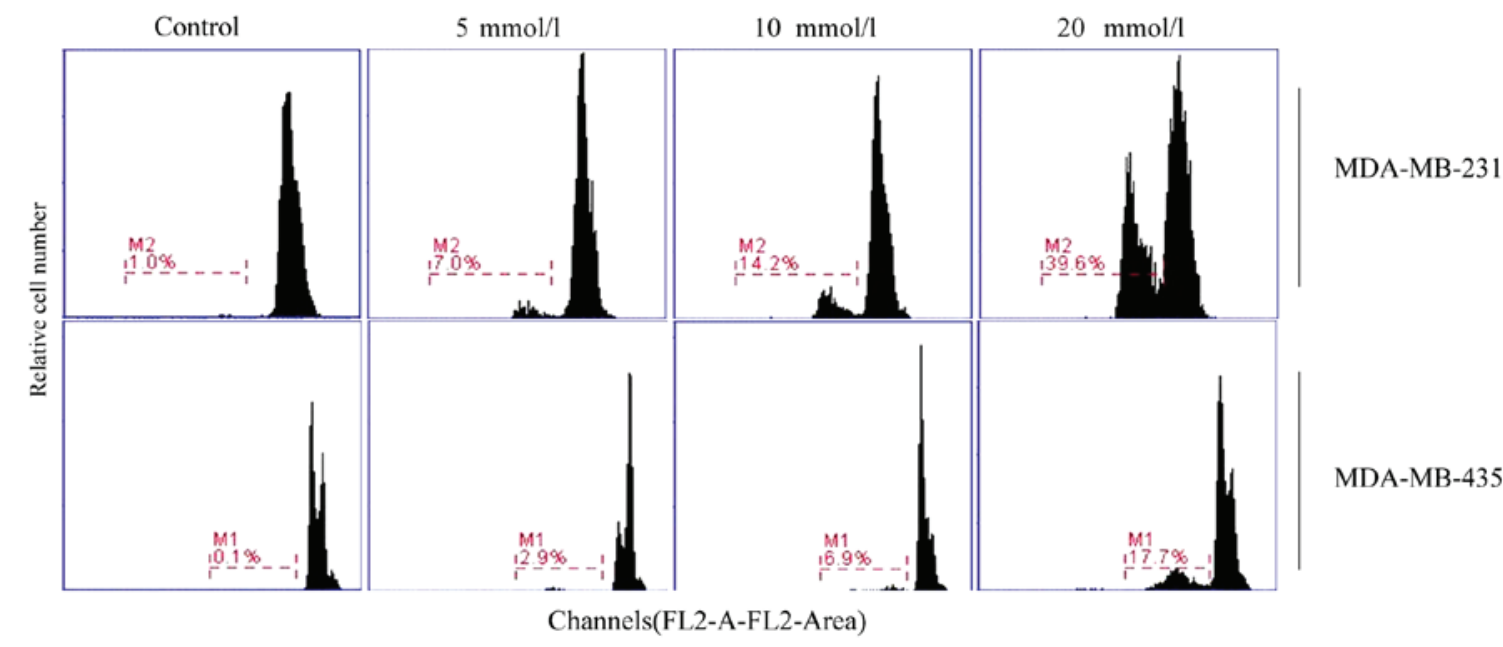

Figure 3. ROS production and apoptosis in MDA-MB-231 and MDA-MB-435 cells treated with metformin. (A) ROS were measured in MDA-MB-231 and MDA-MB-435 cells treated with metformin $(20 \mathrm{mmol} / \mathrm{l})$ for 1,3 and $6 \mathrm{~h}$. Cells were loaded with DHE $(5 \mathrm{mmol} / \mathrm{l})$ and viewed using fluorescence microscopy. In the graph, cell number is presented on the $\mathrm{y}$-axis and fluorescence intensity on the $\mathrm{x}$-axis. The fluorescence intensity gradually increased over time, suggesting significant generation of intracellular ROS in metformin-treated cells compared with untreated control cells. (B) MDA-MB-231 and MDA-MB-435 cells were cultured with various concentrations of metformin $(0,5,10$ and $20 \mathrm{mmol} / \mathrm{l})$ for $24 \mathrm{~h}$, then loaded with propidium iodide before flow cytometric analysis to assess apoptosis. ROS, reactive oxygen species; DHE, dihydroethidium.

A

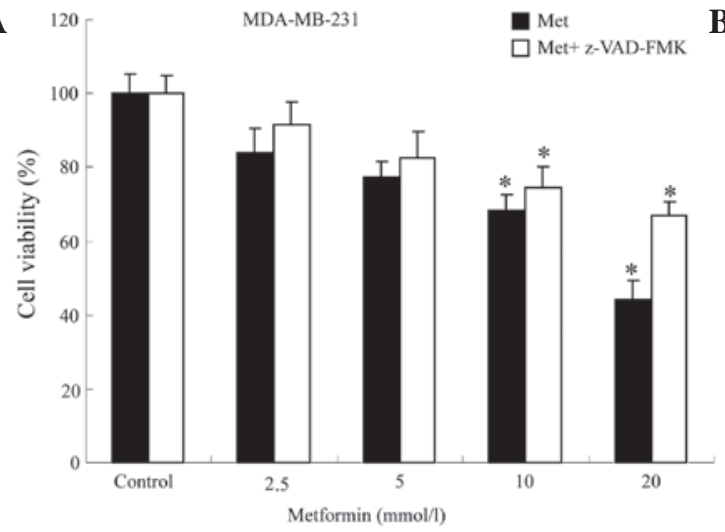

B
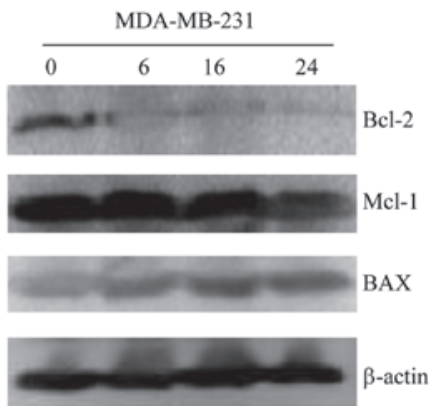

Figure 4. Metformin-induced apoptosis occurs via the mitochondria-mediated apoptotic pathway. (A) MDA-MB-231 cells were treated with metformin (0, 2.5, $5,10$ and $20 \mathrm{mmol} / \mathrm{l})$ with or without z-VAD-FMK $(20 \mu \mathrm{M})$ for $24 \mathrm{~h}$. Viability was then assessed using the MTT assay. Data are expressed as the means \pm standard error of the mean ("P $<0.05$ vs. the control). (B) Whole-cell lysates from MDA-MB-231 cells treated with $5 \mathrm{mmol} / 1 \mathrm{metformin}$ for 6,16 , and $24 \mathrm{~h}$ were used to measure apoptosis-related proteins by western blot analyses. The blots shown are representative of three independent experiments. BAX protein levels were time-dependently increased. BCL-2 and MCL-1 levels were time-dependently decreased. BAX, BCL-2-associated X protein; BLC-1, B-cell lymphoma 2; MCL-1, myeloid cell leukemia-1.

the role of caspases in the process. The results of the MTT assay revealed that the viability of MDA-MB-231 cells was significantly attenuated by z-VAD-FMK, confirming that the process is caspase-dependent (Fig. 4A).
Metformin changes the expression of apoptosis-associated proteins. To confirm whether metformin-induced apoptosis activates the mitochondrial pathway, MDA-MB-231 cells were incubated in the absence or presence of metformin and then 
harvested for western blot analyses. Since the mitochondrial pathway appeared to be involved in the induction of intrinsic apoptosis, the levels of anti- and pro-apoptotic proteins that dysregulate the mitochondrial balance were measured. Incubation of cells with metformin time-dependently upregulated the levels of the pro-apoptotic protein BAX and downregulated the levels of the anti-apoptotic proteins BCL-2 and MCL-1 (Fig. 4B). This indicates that metformin-induced apoptosis is a mitochondria-mediated process.

\section{Discussion}

Recent studies have shown that metformin exerts antitumor effects in vivo and in vitro (23-25). In addition, metformin has been demonstrated to exert anticancer activity against hepatocellular carcinoma through inhibition of the mechanistic target of rapamycin (mTOR) translational pathway in an AMP-activated protein kinase (AMPK)-independent manner. This leads to G1 arrest in the cell cycle and subsequent cell apoptosis through the mitochondria-dependent pathway (26). Nonetheless, the mechanisms underlying these actions remain unknown in breast cancer.

Apoptosis suppresses cell proliferation (27), and the BCL-2 family of proteins plays an important role in the response to apoptosis of different cell types, including myocardial, endothelial and cancer cells (28-31). Furthermore, these proteins are primarily responsible for initiating apoptosis through an intrinsic (mitochondrial) pathway, where signals directly received by the cells can initiate a cascade of events leading to a commitment to cell death $(32,33)$. BAX, a pro-apoptotic member of the BCL-2 protein family, which normally localizes to the cytosolic compartment, translocates to and oligomerizes on the outer mitochondrial membrane to form channels through the membrane. The relative ratio of pro-apoptotic proteins, such as BAX, to anti-apoptotic proteins, such as BCL-2, determines cell survival or death. Thus, a high ratio of BAX/BCL-2 is associated with greater vulnerability to apoptotic activation (34).

Metformin is a partial inhibitor of complex 1 of the mitochondrial electron transport chain $(35,36)$, causing an abnormal flow of electrons to oxygen and leading to the accumulation of ROS within the mitochondrial matrix. ROS are considered to be involved in the pathogenesis of various diseases, including cancer and inflammation. ROS are also necessary for tumor cell proliferation, secretion, differentiation and defense. However, high levels of ROS can induce tumor cell apoptosis and senescence (37). The mitochondrial pathway is important for the induction of apoptosis by chemotherapeutic agents. Moreover, ROS induce the collapse of the $\Delta \psi \mathrm{m}$, thereby triggering a series of mitochondria-associated events, including apoptosis (38).

The potency of metformin against cancer cells has been linked to the generation of ROS (39-41). Consistent with these previous reports, the results of the present study indicated that metformin increased the level of ROS in MDA-MB-231 and MDA-MB-435 cells. A reduction of $\Delta \psi \mathrm{m}$ also induces apoptosis by releasing pro-apoptotic factors such as cytochrome $c$ from the mitochondrial inner space to the cytosol. Cytosolic cytochrome $c$ participates in the activation of caspase- 8 and caspase-9. This, in turn, activates the executioner caspase-3 to induce cell apoptosis (42). In the present study, metformin treatment significantly increased the ROS level, decreased $\Delta \psi \mathrm{m}$, and activated caspase family enzymes in MDA-MB-231 and MDA-MB-435 cells. In addition, metformin increased the expression of the pro-apoptotic protein BAX and decreased levels of the anti-apoptotic proteins BCL-2 and MCL-1 in MDA-MB-231 cells, leading to an increased ratio of BAX/BCL-2. This result concurs with other reports showing that a high BAX/BCL-2 ratio is associated with cytochrome $c$ release and a reduction in $\Delta \psi \mathrm{m}$ (43).

In conclusion, the present study demonstrated that metformin treatment effectively reduced cell viability and induced apoptotic cell death in human breast cancer cells. Metformin also induced activation of the caspase-dependent pathway, accumulation of ROS, and a reduction in $\Delta \Psi_{\mathrm{m}}$ and ATP production in human breast cancer cells. These results suggest that metformin-induced apoptosis is mediated by the accumulation of ROS via the mitochondria-mediated apoptotic pathway. This study provides further support for the development of metformin as a novel therapeutic agent for the treatment of human breast cancer.

\section{Acknowledgements}

The present study was supported by a grant from the Natural Science Foundation of China (grant no. 81272739).

\section{References}

1. Carter D: New global survey shows an increasing cancer burden. Am J Nurs 114: 17, 2014.

2. Taha FM, Zeeneldin AA, Helal AM, Gaber AA, Sallam YA, Ramadan $H$ and Moneer MM: Prognostic value of serum vascular endothelial growth factor in Egyptian females with metastatic triple negative breast cancer. Clin Biochem 42: 1420-1426, 2009.

3. Coelho BA, Belo AV, Andrade SP, Amorim WC, Uemura G and da Silva Filho AL: N-acetylglucosaminidase, myeloperoxidase and vascular endothelial growth factor serum levels in breast cancer patients. Biomed Pharmacother 68: 185-189, 2014.

4. Breidenbach M, Rein DT, Schöndorf T, Khan KN, Herrmann I, Schmidt T, Reynolds PN, Vlodavsky I, Haviv YS and Curiel DT: A new targeting approach for breast cancer gene therapy using the heparanase promoter. Cancer Lett 240: 114-122, 2006.

5. Gnant M, Balic M, Petru E, Raunik W, Singer CF, Steger GG, Watzke IM and Brodowicz T: Treatment of bone metastases in patients with advanced breast cancer. Breast Care (Basel) 7: 92-98, 2012.

6. Coleman RE: Clinical features of metastatic bone disease and skeletal morbidity. Clin Cancer Res 12: 6243s-6249s, 2006.

7. Sano M, Hayashi E, Murakami H, Kishimoto H, Fukuzawa R and Nemoto N: Mcl-1, an anti-apoptotic Bcl-2 family member, essentially overlaps with insulin-producing cells in nesidioblastosis. Virchows Arch 452: 469-470, 2008.

8. Arnoult D, Parone P, Martinou JC, Antonsson B, Estaquier J and Ameisen JC: Mitochondrial release of apoptosis-inducing factor occurs downstream of cytochrome c release in response to several proapoptotic stimuli. J Cell Biol 159: 923-929, 2002.

9. Fulda $\mathrm{S}$ and Debatin KM: Extrinsic versus intrinsic apoptosis pathways in anticancer chemotherapy. Oncogene 25: 4798-4811, 2006.

10. Debatin KM: Apoptosis pathways in cancer and cancer therapy. Cancer Immunol Immunother 53: 153-159, 2004.

11. Algire C, Amrein L, Zakikhani M, Panasci L and Pollak M: Metformin blocks the stimulative effect of a high-energy diet on colon carcinoma growth in vivo and is associated with reduced expression of fatty acid synthase. Endocr Relat Cancer 17: 351-360, 2010.

12. Zhang ZJ, Zheng ZJ, Kan H, Song Y, Cui W, Zhao G and Kip KE: Reduced risk of colorectal cancer with metformin therapy in patients with type 2 diabetes: A meta-analysis. Diabetes Care 34: 2323-2328, 2011. 
13. Zhang ZJ, Zheng ZJ, Shi R, Su Q, Jiang Q and Kip KE: Metformin for liver cancer prevention in patients with type 2 diabetes: A systematic review and meta-analysis. J Clin Endocrinol Metab 97: 2347-2353, 2012.

14. Emami Riedmaier A, Fisel P, Nies AT, Schaeffeler E and Schwab M: Metformin and cancer: From the old medicine cabinet to pharmacological pitfalls and prospects. Trends Pharmacol Sci 34: 126-135, 2013.

15. Nair V, Pathi S, Jutooru I, Sreevalsan S, Basha R, Abdelrahim M, Samudio I and Safe S: Metformin inhibits pancreatic cancer cell and tumor growth and downregulates SP transcription factors. Carcinogenesis 34: 2870-2879, 2013.

16. Bayraktar S, Hernadez-Aya LF, Lei X, Meric-Bernstam F, Litton JK, Hsu L, Hortobagyi GN and Gonzalez-Angulo AM: Effect of metformin on survival outcomes in diabetic patients with triple receptor-negative breast cancer. Cancer 118: 1202-1211, 2012.

17. He X, Esteva FJ, Ensor J, Hortobagyi GN, Lee MH and Yeung SC: Metformin and thiazolidinediones are associated with improved breast cancer-specific survival of diabetic women with HER2+ breast cancer. Ann Oncol 23: 1771-1780, 2012.

18. Hou G, Zhang S, Zhang X, Wang P, Hao X and Zhang J: Clinical pathological characteristics and prognostic analysis of 1,013 breast cancer patients with diabetes. Breast Cancer Res Treat 137: 807-816, 2013.

19. Lega IC, Austin PC, Gruneir A, Goodwin PJ, Rochon PA and Lipscombe LL: Association between metformin therapy and mortality after breast cancer: A population-based study. Diabetes Care 36: 3018-3026, 2013

20. Shirakata $Y$ and Koike K: Hepatitis B virus $X$ protein induces cel death by causing loss of mitochondrial membrane potential. J Biol Chem 278: 22071-22078, 2003.

21. Zamzami N, Marchetti P, Castedo M, Decaudin D, Macho A, Hirsch T, Susin SA, Petit PX, Mignotte B and Kroemer G: Sequential reduction of mitochondrial transmembrane potential and generation of reactive oxygen species in early programmed cell death. J Exp Med 182: 367-377, 1995.

22. Gottlieb E, Vander Heiden MG and Thompson CB: Bcl-x (L) prevents the initial decrease in mitochondrial membrane potential and subsequent reactive oxygen species production during tumor necrosis factor alpha-induced apoptosis. Mol Cell Biol 20: $5680-5689,2000$

23. Bao B, Wang Z, Ali S, Ahmad A, Azmi AS, Sarkar SH, Banerjee S, Kong D, Li Y, Thakur S and Sarkar FH: Metformin inhibits cell proliferation, migration and invasion by attenuating CSC function mediated by deregulating miRNAs in pancreatic cancer cells. Cancer Prev Res (Phila) 5: 355-364, 2012.

24. Chen TW, Liang YN, Feng D, Tao LY, Qi K, Zhang HY, Wang HX, Lin QS and Kong H: Metformin inhibits proliferation and promotes apoptosis of HER-2 positive breast cancer cells by downregulating HSP90. J BUON 18: 51-56, 2013.

25. Erices R, Bravo ML, Gonzalez P, Oliva B, Racordon D, Garrido M, Ibañez C, Kato S, Brañes J, Pizarro J, et al: Metformin at concentrations corresponding to the treatment of diabetes, potentiates the cytotoxic effects of carboplatin in cultures of ovarian cancer cells. Reprod Sci 20: 1433-1446, 2013.

26. Xiong Y, Lu QJ, Zhao J and Wu GY: Metformin inhibits growth of hepatocellular carcinoma cells by inducing apoptosis via mitochondrion-mediated pathway. Asian Pac J Cancer Prev 13: $3275-3279,2012$
27. Circu ML and Aw TY: Glutathione and modulation of cell apoptosis. Biochim Biophys Acta 1823: 1767-1777, 2012.

28. Smith MA and Schnellman RG: Calpains, mitochondria and apoptosis. Cardiovasc Res 96: 32-37, 2012.

29. Andersen JL and Kornbluth S: The tangled circuitry of metabolism and apoptosis. Mol Cell 49: 399-410, 2013.

30. Petsophonsakul P, Pompimon W and Banjerdpongchai R: Apoptosis induction in human leukemic promyelocytic HL-60 and monocytic U937 cell lines by goniothalamin. Asian Pac J Cancer Prev 14: 2885-2889, 2013.

31. Czabotar PE, Lessene G, Strasser A and Adams JM: Control of apoptosis by the BCL-2 protein family: Implications for physiology and therapy. Nat Rev Mol Cell Biol 15: 49-63, 2014.

32. Cory S and Adams JM: The Bcl2 family: Regulators of the cellular life-or-death switch. Nat Rev Cancer 2: 647-656, 2002.

33. Green DR and Kroemer G: The pathophysiology of mitochondrial cell death. Science 305: 626-629, 2004.

34. Rondelet B, Dewachter C, Kerbaul F, Kang X, Fesler P, Brimioulle S, Naeije R and Dewachter L: Prolonged overcirculation-induced pulmonary arterial hypertension as a cause of right ventricular failure. Eur Heart J 33: 1017-1026, 2012.

35. El-Mir MY, Nogueira V, Fontaine E, Avéret N, Rigoulet M and Leverve X: Dimethylbiguanide inhibits cell respiration via an indirect effect targeted on the respiratory chain complex 1 . J Biol Chem 275: 223-228, 2000.

36. Owen MR, Doran E and Halestrap AP: Evidence that metformin exerts its anti-diabetic effects through inhibition of complex 1 of the mitochondrial respiratory chain. Biochem J 348: 607-614, 2000

37. Behrend L, Henderson G and Zwacka RM: Reactive oxygen species in oncogenic transformation. Biochem Soc Trans 31: 1441-1444, 2003.

38. Simon HU, Haj-Yehia A and Levi-Schaffer F: Role of reactive oxygen species (ROS) in apoptosis induction. Apoptosis 5: 415-418, 2000

39. Aldea MD, Petrushev B, Soritau Q, Tomuleasa CI, Berindan-Neagoe I, Filip AG, Chereches G, Cenariu M, Craciun L, Tatomir C, et al: Metformin plus sorafenib high impacts temozolomide resistant glioblastoma stem-like cells. J Buon 19: 502-511, 2014.

40. Haugrud AB, Zhuang Y, Coppock JD and Miskimins WK: Dichloroacetate enhance apoptotic cell death via oxidative damage and attenuates lactate production in metformin-treated breast cancer cells. Breast Cancer Res Treat 147: 539-550, 2014.

41. Kim EH, Kim MS, Cho CK, Jung WG, Jeong YK and Jeong JH: Low and high linear energy transfer radiation sensitization of HCC cells by metformin. J Radiat Res 55: 432-442, 2014.

42. Wang X: The expanding role of mitochondria in apoptosis Genes Dev 15: 2922-2933, 2001.

43. Ibrahim MY, Hashim NM, Mohan S, Abdulla MA, Kamalidehghan B, Ghaderian M, Dehghan F, Ali LZ, Arbab IA, Yahayu M, et al: $\alpha$-Mangostin from Cratoxylum arborescens demonstrates apoptogenesis in MCF-7 with regulation of NF- $x \mathrm{~B}$ and Hsp70 protein modulation in vitro and tumor reduction in vivo. Drug Des Devel Ther 8: 1629-1647, 2014. 